\title{
High Photovoltage in Perovskite Solar Cells: New Physical Insights from the Ultrafast Transient Absorption Spectroscopy
}

M. Ibrahim Dar ${ }^{a}$, Marius Franckevičius ${ }^{b}, N^{2}$ a Arora ${ }^{a}$, Kipras Redeckas ${ }^{c}$, Mikas Vengris $^{c}$, Vidmantas Gulbinas $^{\mathrm{b}}$, Shaik Mohammed Zakeeruddin ${ }^{\mathrm{a}}$, Michael Grätzel ${ }^{\mathrm{a} *}$

${ }^{a}$ Laboratory of Photonics and Interfaces, Department of Chemistry and Chemical Engineering, Swiss Federal Institute of Technology Lausanne, Lausanne CH-1015, Switzerland.

${ }^{b}$ Center for Physical Sciences and Technology, Sauletekio Ave. 3, LT-10257 Vilnius, Lithuania

${ }^{c}$ Department of Quantum Electronics, Faculty of Physics, Vilnius University, Sauletekio Ave. 10, LT-10223 Vilnius, Lithuania

*Correspondence authors: (M.I.D.) E-mail: $\underline{\text { ibrahim.dar@epfl.ch, }} \quad$ (M.G.) E-mail: $\underline{\text { michael.graetzel@epfl.ch }}$ 


\begin{abstract}
To understand the cause of the high open circuit photovoltage $\left(\mathrm{V}_{\mathrm{OC}}\right)$ achieved by todays' state of the art perovskite solar cells (PSCs), we examine formamidinium lead bromide $\mathrm{CH}\left(\mathrm{NH}_{2}\right)_{2} \mathrm{PbBr}_{3}$ ) films by ultrafast transient absorption spectroscopy (TAS). The devices based on the $\mathrm{CH}\left(\mathrm{NH}_{2}\right)_{2} \mathrm{PbBr}_{3}$ films yield $\mathrm{V}_{\mathrm{OC}}$ as high as $1.5 \mathrm{~V}$ ascertaining their high quality. TAS establish that the presence of charge extraction layers has very little influences on the nature of a negative band at $535 \mathrm{~nm}$ corresponding to the bleaching of the absorption band edge and two positive bands in the $\mathrm{CH}\left(\mathrm{NH}_{2}\right)_{2} \mathrm{PbBr}_{3}$ films. Therefore, we contend that the $\mathrm{V}_{\mathrm{OC}}$ in $\mathrm{PSC}$ is predominantly determined by the quasi Fermi level splitting within the perovskite layer.
\end{abstract}

Keywords: perovskite solar cells, photovoltage, charge carrier dynamics, transient absorption spectroscopy 


\section{Introduction}

Perovskite solar cells (PSC) have shown a remarkable growth in terms of high photovoltaic performance. Within a decade from their inception, the certified power conversion efficiency (PCE) of PSC has already exceeded 22\% [1]. Owing to the extraordinary optoelectronic properties of perovskite absorbers, such a remarkable evolution in the PCE has been realized [2].

For the first time Kojima et al. reported a PCE of $3.8 \%$ when mesoporous $\mathrm{TiO}_{2}$ was sensitized with $\mathrm{CH}_{3} \mathrm{NH}_{3} \mathrm{PbI}_{3}$, subsequently, Park and coworkers improved the PCE to $>5 \%[3,4]$. In both reports, the liquid dye-sensitized solar cell (DSC) architecture was retained. Ageing tests revealed that these solar cells are unstable, and such issues were found to be associated with the dissolution of perovskite material in the liquid electrolyte. Intuitively, the solid-state DSC architecture was an alternative option, which was adopted and PCE exceeding 9\% was reported by Park and co-workers, and Snaith and co-workers $[5,6]$.

Although record efficiency yielding PSCs still involve charge extraction layers which were actually used for solid-state DSC, there are certain sharp differences [7,8]. For example, unlike dye molecules, perovskite absorbers are ambipolar in nature [6] and the $V_{O C}$ has been found to show minimal dependence on the band positions in the charge extraction layers [9]. Using mesoporous $\mathrm{TiO}_{2}$ and spiro-OMeTAD, respectively, as electron and hole extraction layers, which were initially introduced by Graetzel and co-workers in the solid-state DSC [10], high V VC could be extracted from the bromide PSC. Using mesoporous $\mathrm{Al}_{2} \mathrm{O}_{3}$ as an insulating scaffold, Cahen and coworker, reported a $\mathrm{V}_{\mathrm{OC}}$ of $1.3 \mathrm{~V}$ for $\mathrm{CH}_{3} \mathrm{NH}_{3} \mathrm{PbBr}_{3}$ based devices [11]. Arora et al. demonstrated the deposition of high quality of $\mathrm{CH}\left(\mathrm{NH}_{2}\right)_{2} \mathrm{PbBr}_{3}$ films and their application in PSC for achieving a $\mathrm{V}_{\mathrm{OC}}$ of $1.42 \mathrm{~V}$ [12]. After improving the growth of $\mathrm{CH}_{3} \mathrm{NH}_{3} \mathrm{PbBr}_{3}$ layer by inducing the heterogeneous nucleation using $\mathrm{HBr}, \mathrm{Im}$ and co-worker achieved a $\mathrm{V}_{\mathrm{OC}}$ of $1.5 \mathrm{~V}$ 
[13]. Recently, Arora et al. achieved a photovoltage of $1.53 \mathrm{~V}$ for $\mathrm{CH}\left(\mathrm{NH}_{2}\right)_{2} \mathrm{PbBr}_{3}$ solar cells by modifying the interface between mesoporous $\mathrm{TiO}_{2}$ and $\mathrm{CH}\left(\mathrm{NH}_{2}\right)_{2} \mathrm{PbBr}_{3}$ layer using lithium treatment [14].

Recently, remarkable efficiencies have brought PSCs to the forefront of the photovoltaic application; however, their fundamental studies are still evolving, For example, the origin of the outstanding photovoltage $\left(\mathrm{V}_{\mathrm{OC}}\right)$ exhibited by PSC still needs to be explored as this is a key photovoltaic metrics that has led to an exceptional evolution in their performance. To gain deeper physical insights into the high $\mathrm{V}_{O C}$, we selected the relatively less explored $\mathrm{CH}\left(\mathrm{NH}_{2}\right)_{2} \mathrm{PbBr}_{3}$ perovskite material which is distinguished by a high stability as a case study system [15]. We unraveled the influence of charge extraction layers on the excited state charge carrier dynamics by ultrafast transient absorption spectroscopy (TAS), and correlated the results with the outstanding $\mathrm{V}_{\mathrm{OC}}$ displayed by the $\mathrm{CH}\left(\mathrm{NH}_{2}\right)_{2} \mathrm{PbBr}_{3}$ solar cells.

\section{Materials and methods}

All materials were purchased from Sigma-Aldrich and were used as received unless stated otherwise.

\subsection{Preparation of $\mathrm{TiO}_{2}$ photoanode}

Fluorine-doped tin oxide (FTO)-glass substrates (NSG 10, Nippon sheet glass, Japan) were cleaned by ultrasonication in Hellmanex ( $2 \%$, deionized water), rinsed thoroughly with deionized water and ethanol, and then treated in oxygen plasma for 15 min. Using a commercial titanium diisopropoxide bis(acetylacetonate) solution (75\% in 2-propanol, Sigma-Aldrich) diluted in anhydrous ethanol (1:9, volume ratio) as precursor and oxygen as a carrier gas, a 
compact layer of $\mathrm{TiO}_{2}$ of ca $30 \mathrm{~nm}$ was subsequently deposited via spray pyrolysis at $450{ }^{\circ} \mathrm{C}$. A mesoporous $\mathrm{TiO}_{2}$ layer was then deposited by spin coating a diluted paste (1:3.5 wt. ratio) (Dyesol 30NRD: ethanol) (5000 rpm, acceleration $2000 \mathrm{rpm}$ for $30 \mathrm{~s}$ ) atop of the compact $\mathrm{TiO}_{2}$ layer. This was followed by a series of sintering steps $\left(325{ }^{\circ} \mathrm{C}\right.$ for 5 min with $15 \mathrm{~min}$ ramp time, $375^{\circ} \mathrm{C}$ for 5 min with $5 \mathrm{~min}$ ramp time, $450{ }^{\circ} \mathrm{C}$ for 30 min with $5 \mathrm{~min}$ ramp time) in dry air. For lithium treatment of mesoporous $\mathrm{TiO}_{2}$ photoanode, $200 \mu \mathrm{L}$ of bis(trifluoromethylsulfonyl)imide lithium salt solution in acetonitrile $(20 \mathrm{mg} / \mathrm{mL}$, freshly prepared in argon atmosphere) was spin coated (3000 rpm, acceleration $2000 \mathrm{rpm}$ for $20 \mathrm{~s}$ ) after a loading time of $10 \mathrm{~s}$, and the substrates were subjected to a second sintering step at $450{ }^{\circ} \mathrm{C}$ for $30 \mathrm{~min} .250 \mathrm{~nm}$-thick $\mathrm{Al}_{2} \mathrm{O}_{3}$ mesoporous layer composed of $30 \mathrm{~nm} \mathrm{Al}_{2} \mathrm{O}_{3}$ nanoparticles was deposited on non-conducting glass substrate by spin coating diluted paste (1:3.5 wt. ratio) $(5000 \mathrm{rpm}$, acceleration $2000 \mathrm{rpm}$ for $30 \mathrm{~s})$. The mesoporous $\mathrm{Al}_{2} \mathrm{O}_{3}$ films were obtained after sintering the substrates at $450{ }^{\circ} \mathrm{C}$ for 30 min with 10 min ramp time.

\subsection{Device fabrication}

$\mathrm{CH}\left(\mathrm{NH}_{2}\right)_{2} \mathrm{PbBr}_{3}$ films were deposited using two-step sequential deposition method [15]. 1.2 M $\mathrm{PbBr}_{2}$ (TCI 99\%) precursor solution was prepared in $N, N$-dimethylformamide (DMF, Acros Organics) and dimethylsulphoxide (DMSO, Acros Organics) by constant stirring at $60{ }^{\circ} \mathrm{C}$ for 30 minutes. $\mathrm{PbBr}_{2}$ (DMF+DMSO in 1:1 volume ratio) solution was spin-coated onto the mesoporous $\mathrm{TiO}_{2}$ films at $3000 \mathrm{rpm}$ for $30 \mathrm{~s}$. After heating at $80{ }^{\circ} \mathrm{C}$ for $15 \mathrm{~min}$, the $\mathrm{PbBr}_{2}$ films were dipped into $\mathrm{CH}\left(\mathrm{NH}_{2}\right)_{2}$ solution (Dyesol, $50 \mathrm{mM}$ ) in isopropanol for $5 \mathrm{~min}$ at $60{ }^{\circ} \mathrm{C}$, rinsed with 2-propanol for $5 \mathrm{~s}$ and dried at $80{ }^{\circ} \mathrm{C}$ for $30 \mathrm{~min}$. $72.3 \mathrm{mg}$ spiro-OMeTAD $\left(2,2^{\prime}, 7,7^{\prime}-\right.$ tetrakis( $N, N$-di-p-methoxyphenylamine)-9,9-spirobifluorene) was dissolved in $1 \mathrm{~mL}$ of chlorobenzene, to which $28.8 \mu \mathrm{L}$ 4-tert-butylpyridine, $17.5 \mu \mathrm{L}$ of a stock solution of 
$520 \mathrm{mg} \mathrm{mL}^{-1}$ bis(trifluoromethylsulfonyl)imide lithium salt in acetonitrile, and $29 \mu \mathrm{L}$ of a stock solution of $\quad 300 \mathrm{mg} \mathrm{mL}^{-1}$ tris(2-(1H-pyrazol-1-yl)-4-tert-butylpyridine)cobalt(III) bis(trifluoromethylsulphonyl)imide in acetonitrile were added. The device fabrication was carried out under controlled atmospheric conditions with humidity $<1 \%$. Finally, device fabrication was completed by thermally evaporating $\sim 70 \mathrm{~nm}$ of gold layer as a back contact.

\subsection{Morphological characterization}

Field-emission scanning electron microscope (FESEM, Merlin) was employed to analyze the morphology of the $\mathrm{CH}\left(\mathrm{NH}_{2}\right)_{2} \mathrm{PbBr}_{3}$ devices. An electron beam accelerated to $3 \mathrm{kV}$ was used with an in-lens detector.

\subsection{Device characterization}

The current-voltage (J-V) characteristics of the $\mathrm{CH}\left(\mathrm{NH}_{2}\right)_{2} \mathrm{PbBr}_{3}$ devices were recorded with a digital source meter (Keithley model 2400, USA). A 450 W xenon lamp (Oriel, USA) was used as the light source for photovoltaic measurements. The spectral output of the lamp was filtered using a Schott K113 Tempax sunlight filter (Präzisions Glas \& Optik GmbH, Germany) to reduce the mismatch between the simulated and actual solar spectrum to less than $2 \%$. The photo-active area of $0.16 \mathrm{~cm}^{2}$ was defined using a dark-coloured metal mask.

\subsection{Spectroscopic characterization}

UV-Vis extinction spectra were recorded with a Jasco V-670 spectrophotometer in the range of 300-1000 $\mathrm{nm}$. The experimental setup used for the femtosecond-resolution absorption pumpprobe experiments was introduced in Ref [16]. In brief, the measurement system is based on the Ti:Sa femtosecond system COHERENT LIBRA ( $3.5 \mathrm{~W}, 50 \mathrm{fs}, 987 \mathrm{~Hz})$. The pump radiation at 
$500 \mathrm{~nm}$ was generated with a travelling-wave optical parametric amplifier (OPA) TOPAS-800 pumped with ca. $20 \%$ of the fundamental Ti:Sa system output. White light supercontinuum generated in a mechanically translated $3 \mathrm{~mm}$ thick $\mathrm{CaF}_{2}$ plate was used as the broadband probe light. Polarizations of pump and probe beams were set at the "magic" angle $\left(54.7^{\circ}\right)$. The probe beam was dispersed using a Czerny-Turner type imaging spectrograph (NEWPORT ORIEL 127I) and the entire NUV-to-NIR probe spectrum was digitized and read out with the 512 pixel linear photodiode array (HAMAMATSU 8380-512Q). In order to avoid permanent damage, the sample films were slowly (ca. $0.1 \mathrm{~mm} / \mathrm{s}$ ) translated transversely to the beam propagation direction using two perpendicularly-aligned motorized linear stages.

\section{Results and discussion}

Fig. 1a shows cross sectional scanning electron microscopy (SEM) micrograph of the complete $\mathrm{CH}\left(\mathrm{NH}_{2}\right)_{2} \mathrm{PbBr}_{3}$ solar cell, which clearly brings out the thickness of various layers comprising the device. Typically, the device fabrication involves the deposition of $\sim 400 \mathrm{~nm}$ thick $\mathrm{CH}\left(\mathrm{NH}_{2}\right)_{2} \mathrm{PbBr}_{3}$ onto $\sim 250 \mathrm{~nm}$ thick mesoporous $\mathrm{TiO}_{2}$ supported on a transparent conducting glass containing pre-deposited compact $(\sim 30 \mathrm{~nm}) \mathrm{TiO}_{2}$ layer. Subsequently, the device is completed by depositing $\sim 180 \mathrm{~nm}$ thick spiro-OMeTAD layer and by thermally evaporating a $\sim 70 \mathrm{~nm}$ thick gold layer as a back contact. The photovoltaic performance of the resulting devices was investigated by recording the current-voltage (JV) characteristics under standard full sun illumination (Fig. 1b). The $\mathrm{CH}\left(\mathrm{NH}_{2}\right)_{2} \mathrm{PbBr}_{3}$ device showed a short circuit current density $\left(\mathrm{J}_{\mathrm{SC}}\right)$ of $6.86 \mathrm{~mA} / \mathrm{cm}^{2}$, an open-circuit voltage $\left(\mathrm{V}_{\mathrm{OC}}\right)$ of $1.5 \mathrm{~V}$, and a fill factor (FF) of $70 \%$ resulting in an overall PCE of $7.3 \%$. In addition, the device exhibited a negligible hysteresis (Fig. S1). Such photovoltaic parameters are in close agreement with the literature [14]. 
Given the conduction band position of $\mathrm{TiO}_{2}$ and the highest occupied molecular orbital (HOMO) of spiro-OMeTAD, respectively, as 4.0 and $5.1 \mathrm{eV}$, a $\mathrm{V}_{\mathrm{OC}}$ of $\sim 1.1 \mathrm{~V}$ is expected [17]. However, we obtain a $\mathrm{V}_{\mathrm{OC}}$ of $1.5 \mathrm{~V}$ for our $\mathrm{CH}\left(\mathrm{NH}_{2}\right)_{2} \mathrm{PbBr}_{3}$ devices that cannot be rationalized using this simplistic approach and therefore demands critical evaluation.

In principle, nature of charge carrier recombination dynamics dictate the efficiency of the light harnessing and light emitting devices [18].. Therefore, to understand the excited state dynamics of charge carriers, $\mathrm{CH}\left(\mathrm{NH}_{2}\right)_{2} \mathrm{PbBr}_{3}$ films were examined by means of ultrafast transient absorption spectroscopy (TAS). Transient absorption (TA) spectra and decay kinetics of $\mathrm{CH}\left(\mathrm{NH}_{2}\right)_{2} \mathrm{PbBr}_{3}$ perovskite films deposited onto insulating mesoporous $\mathrm{Al}_{2} \mathrm{O}_{3}$ excited at $500 \mathrm{~nm}$ are shown in Fig. 2. The steady state absorption spectrum is also plotted for clarity. Transient absorption spectra show a negative band at $535 \mathrm{~nm}$ corresponding to the bleaching of the absorption band edge and two positive bands on either side of the negative band (Fig. 2a). The TA spectral features of $\mathrm{CH}\left(\mathrm{NH}_{2}\right)_{2} \mathrm{PbBr}_{3}$ perovskite are quite similar to those observed in other related perovskites, thus could be explained using existing conceptions $[19,20]$. The bleaching band is attributed to the valence band (VB) depopulation [21] and the positive long-lived induced absorption band in a 490-520 $\mathrm{nm}$ region arises due to refractive index change [20] The bleaching band shows an initial fast red shift, which could be attributed to the exciton-exciton interaction [22]. The photo-induced bleach is directly related to the carrier density, thus by tracking absorption recovery, we can characterize carrier recombination and extraction processes.

Immediately after photoexcitation, hot charge carriers are generated resulting in the appearance of a short lived positive TA signal slightly above the band gap at about $550 \mathrm{~nm}$. Subsequently, carrier cooling takes place on a hundreds of femtoseconds (fs) time scale as 
reflected by TA decay kinetics (Fig. 2b). The thermalization lifetime in the $\mathrm{CH}\left(\mathrm{NH}_{2}\right)_{2} \mathrm{PbBr}_{3}$ perovskite could be attributed to the hot-phonon bottleneck effect [20,23].

To gain more information about the charge carrier recombination process in $\mathrm{CH}\left(\mathrm{NH}_{2}\right)_{2} \mathrm{PbBr}_{3}$ perovskite films, we additionally measured the TA kinetics at various excitation intensities (5-100 $\mu \mathrm{J} \cdot \mathrm{cm}^{-2}$ ) (Fig 3). Assuming that bimolecular recombination merely governs the carrier dynamics on a several nanosecond (ns) time scale, we can express the carrier decay kinetics by the rate equation $d n / d t=-\gamma(t) n^{2}$. For disordered systems, the time-dependent recombination may be approximated by the rate law $\gamma(t)=\gamma_{0} t^{-\alpha}$, [24] and solution of the rate equation gives the carrier concentration kinetics: $1 / \mathrm{n}-1 / \mathrm{n}_{0}=\gamma_{0} t^{l-\alpha} /(1-\alpha)$ Assumming that the carrier concentration is proportional to $\Delta A$, we plot $1 / \Delta A-1 / \Delta A_{0}=f(\mathrm{t})$ in double logarithmic coordinates. In this representation, concentration kinetics at different excitation intensities coincides and closely follows a linear dependence validating the proposed approach. Slope of the curves gives $\alpha \approx 0.35$, which shows that the carrier recombination rate at all excitation intensities decreases with time as $t^{-0.35}$. The time-dependence of the recombination rate apparently originates from the polycrystalline perovskite structure, where grain boundaries create obstacles for the carrier motion reducing carrier recombination rate at longer times when carriers migrate between crystallites. Excitation intensity-independent kinetics also indicates that carrier trapping and trap saturation suggested in the literature do not take place in our samples in the investigated time domain [25]. Some deviation from the linear dependence at long times observed at very high excitation intensities indicates that carrier decay rate in these conditions is slightly faster than determined by the $t^{-0.35}$. Such a dependence cannot be caused by the trap saturation, which is expected to give opposite deviation. This reflects a complex recombination kinetics in the polycrystalline fractal-like structure. 
To study the effect of electron and hole transporting materials on the carrier dynamics, we measured TA kinetics in $\mathrm{CH}\left(\mathrm{NH}_{2}\right)_{2} \mathrm{PbBr}_{3}$ films interfaced with the mesoporous $\mathrm{TiO}_{2}$ layer or spiro-MeOTAD or both layers (Fig 4). Negligible enhancement of the carrier decay rate on a several nanosecond time scale was observed for $\mathrm{CH}\left(\mathrm{NH}_{2}\right)_{2} \mathrm{PbBr}_{3}$ perovskites. It shows that the carrier injection from photoexcited perovskite into the charge extraction layers is slow in comparison with the investigated time domain. This also agrees with the results of previous studies showing that the charge extraction from other perovskites occur on tens to hundreds of nanoseconds time scale [26].

Fig. 5 schematically illustrates various processes, including charge injection, charge carrier recombination and relaxation occurring within the PSC after photoexcitation. Vertical dotted arrows represent excitation of electrons from the VB of perovskite into its $\mathrm{CB}$, red solid curves describe injection of electrons and holes, respectively, into the $\mathrm{CB}$ of $\mathrm{TiO}_{2}$ and the HOMO of spiro-OMeTAD. Relatively thick inverted yellow colored arrow represents a radiative recombination occurring within the perovskite absorber layer. In other words, the radiative recombination of charge carriers majorly occur within the $\mathrm{CH}\left(\mathrm{NH}_{2}\right)_{2} \mathrm{PbBr}_{3}$ layer immediately after photo-excitation, which evidently contends that the band positions in the charge extraction layers play negligible role in determining $\mathrm{V}_{\mathrm{OC}}$ in PSC. Furthermore, as the position of $\mathrm{CB}$ in $\mathrm{TiO}_{2}$ and $\mathrm{HOMO}$ of spiro-OMeTAD is 4.0 and $5.1 \mathrm{eV}$, respectively, a $\mathrm{V}_{\mathrm{OC}}$ of $\sim 1.5 \mathrm{~V}$ will be difficult to explain using the conventional approach.

\section{Conclusion}

While using mesoporous $\mathrm{TiO}_{2}$ and spiro-OMeTAD as charge extraction layers, the devices based on $\mathrm{CH}\left(\mathrm{NH}_{2}\right)_{2} \mathrm{PbBr}_{3}$ films revealed outstanding $\mathrm{V}_{\mathrm{OC}}$ of $1.5 \mathrm{~V}$, ascertaining their high quality. To 
understand the causation of such a remarkable $\mathrm{VOC}$, the $\mathrm{CH}\left(\mathrm{NH}_{2}\right)_{2} \mathrm{PbBr}_{3}$ films deposited onto mesoporous $\mathrm{Al}_{2} \mathrm{O}_{3}$ were examined by ultrafast transient absorption spectroscopy as the charge carrier dynamics occurring within the absorber layer critically influence the $V_{O C}$. Transient absorption spectra show a negative band at $535 \mathrm{~nm}$ corresponding to the bleaching of the absorption band edge. Due to the generation of hot carriers, a short lived positive TA signal at $\sim 550 \mathrm{~nm}$ appears, which decays on a hundreds of fs time scale. Astoundingly, the impact of extraction layers, i.e., $\mathrm{TiO}_{2}$ and spiro-OMeTAD, on the nature of charge carrier dynamics occurring within the $\mathrm{CH}\left(\mathrm{NH}_{2}\right)_{2} \mathrm{PbBr}_{3}$ films was found to be insignificant. From the results obtained through TAS, we establish that the quasi Fermi level splitting within the $\mathrm{CH}\left(\mathrm{NH}_{2}\right)_{2} \mathrm{PbBr}_{3}$ layer predominantly determine the $\mathrm{V}_{\mathrm{OC}}$ or the presence of charge extraction layers minimally influence the $\mathrm{V}_{\mathrm{OC}}$ in the PSCs.

\section{Acknowledgement}

M. I. D., S. M. Z. and M. G. thank the King Abdulaziz City for Science and Technology (KACST) and Swiss National Science Foundation (SNSF) for financial support. M.F. and V.G. acknowledge funding from the Research Council of Lithuania via grant No. LAT-07/2016. N. A. gratefully acknowledges financial support from Dyesol.

\section{References}


[1] National Renewable Energy Laboratory Best Research-Cell Efficiencies; www.nrel.gov/ncpv/images/efficiency_chart.jpg.

[2] M.I. Dar, G. Jacopin, S. Meloni, A. Mattoni, N. Arora, A. Boziki, S.M. Zakeeruddin, U. Rothlisberger, M. Grätzel, Sci. Adv. 2 (2016), e1601156.

[3] A. Kojima, K. Teshima, Y. Shirai, T. Miyasaka, J. Am. Chem. Soc. 131 (2009) 6050.

[4] J.-H. Im, C.-R. Lee, J.-W. Lee, S.-W. Park, N.-G. Park, Nanoscale 3 (2011) 4088.

[5] H.-S. Kim, C.-R. Lee, J.-H. Im, K.-B. Lee, T. Moehl, A. Marchioro, S.-J. Moon, R. Humphry-Baker, J.-H. Yum, J.E. Moser, M. Grätzel, N.-G. Park, Sci. Rep. 2 (2012) 591.

[6] M.M. Lee, J. Teuscher, T. Miyasaka, T.N. Murakami, H.J. Snaith, Science 338 (2012) 643.

[7] N.J. Jeon, J.H. Noh, W.S. Yang, Y.C. Kim, S. Ryu, J. Seo, S.I. Seok, Nature 517 (2015) 476.

[8] D. Bi, C. Yi, J. Luo, J.-D. Décoppet, F. Zhang, Shaik M. Zakeeruddin, X. Li, A. Hagfeldt, M. Grätzel, Nature Energy 1 (2016) 16142.

[9] R.A. Belisle, P. Jain, R. Prasanna, T. Leijtens, M.D. McGehee, ACS Energy Letters 1 (2016) 556.

[10] U. Bach, D. Lupo, P. Comte, J.E. Moser, F. Weissortel, J. Salbeck, H. Spreitzer, M. Gratzel, Nature 395 (1998) 583.

[11] E. Edri, S. Kirmayer, M. Kulbak, G. Hodes, D. Cahen, J. Phys. Chem. Lett. 5 (2014) 429.

[12] N. Arora, M.I. Dar, M. Hezam, W. Tress, G. Jacopin, T. Moehl, P. Gao, A.S. Aldwayyan, B. Deveaud, M. Grätzel, M.K. Nazeeruddin, Adv. Funct. Mater. 26 (2016) 2846.

[13] J.H. Heo, D.H. Song, S.H. Im, Adv. Mater. 26 (2014) 8179.

[14] N. Arora, M.I. Dar, M. Abdi-Jalebi, F. Giordano, N. Pellet, G. Jacopin, R.H. Friend, S.M. Zakeeruddin, M. Grätzel, Nano Letters 16 (2016) 7155.

[15] J. Burschka, N. Pellet, S.J. Moon, R. Humphry-Baker, P. Gao, Md.K. Nazeeruddin, M. 
Grätzel, Nature, 499 (2013), 316-319.

[15] A.A. Zhumekenov, M.I. Saidaminov, M.A. Haque, E. Alarousu, S.P. Sarmah, B. Murali, I. Dursun, X.-H. Miao, A.L. Abdelhady, T. Wu, O.F. Mohammed, O.M. Bakr, ACS Energy Letters $1(2016) 32$.

[16] K. Redeckas, V. Voiciuk, R. Steponavičiūtè, V. Martynaitis, A. Šačkus, M. Vengris, , J. Phys. Chem. A 118 (2014) 5642.

[17] W.H. Nguyen, C.D. Bailie, E.L. Unger, M.D. McGehee, J. Am. Chem. Soc. 136 (2014) 10996.

[18] K. Tvingstedt, O. Malinkiewicz, A. Baumann, C. Deibel, H.J. Snaith, V. Dyakonov, H.J. Bolink, Sci. Rep. 4 (2014) 6071.

[19] J.C. Brauer, Y.H. Lee, M.K. Nazeeruddin, N. Banerji, J. Phys. Chem. Lett. 6 (2015) 3675.

[20] M.B. Price, J. Butkus, T.C. Jellicoe, A. Sadhanala, A. Briane, J.E. Halpert, K. Broch, J.M. Hodgkiss, R.H. Friend, F. Deschler, Nat. Commun. 6 (2015) 8420.

[21] J.S. Manser, P.V. Kamat, Nat Photon 8 (2014) 737.

[22] P. Piatkowski, B. Cohen, F. Javier Ramos, M. Di Nunzio, M.K. Nazeeruddin, M. Gratzel, S. Ahmad, A. Douhal, Phys. Chem. Chem. Phys. 17 (2015) 14674.

[23] Y. Yang, D.P. Ostrowski, R.M. France, K. Zhu, J. van de Lagemaat, J.M. Luther, M.C. Beard, Nat Photon 10 (2016) 53.

[24] T. Tiedje, A. Rose, Solid State Comm. 37 (1981) 49.

[25] Y. Yamada, T. Yamada, A. Shimazaki, A. Wakamiya, Yanemitsu J. Phys. Chem. Lett. 7 (2016) 1972.

[26] Q. Shen, Y. Ogomi, J. Chang, S. Tsukamoto, K. Kukihara, T. Oshima, N. Osada, K. Yoshino, K. Katayama, T. Toyoda, S. Hayase, Phys. Chem. Chem. Phys 16 (2014) 19984. 


\section{Figure Captions}

Fig. 1. Morphological analysis and photovoltaic study of $\mathrm{CH}\left(\mathrm{NH}_{2}\right)_{2} \mathrm{PbBr}_{3}$ solar cell. (a) Crosssectional SEM image of a complete device and (b) Current-voltage curve recorded form $\mathrm{CH}\left(\mathrm{NH}_{2}\right)_{2} \mathrm{PbBr}_{3}$ device under standard illumination at $0.05 \mathrm{~V} / \mathrm{s}$ scan rate.

Fig. 2. (a) Transient absorption spectra and (b) decay kinetics of $\mathrm{CH}\left(\mathrm{NH}_{2}\right)_{2} \mathrm{PbBr}_{3}$ perovskite deposited onto insulating mesoporous $\mathrm{Al}_{2} \mathrm{O}_{3}$ layer, following excitation at 500nm with an average pump energy density of $5.5 \mu \mathrm{J} \cdot \mathrm{cm}^{-2}$. The dotted gray line in (a) shows steady state absorption spectrum.

Fig. 3. Intensity dependent transient absorption decay kinetics of $\mathrm{CH}\left(\mathrm{NH}_{2}\right)_{2} \mathrm{PbBr}_{3}$ perovskite at $535 \mathrm{~nm}$ shown as the time dependence of $1 / \Delta A-1 / \Delta A_{0}$.

Fig. 4. Transient absorption spectra of $\mathrm{CH}\left(\mathrm{NH}_{2}\right)_{2} \mathrm{PbBr}_{3}$ perovskite films deposited onto (a) mesoporous $\mathrm{TiO}_{2}$ layer, (b) interfaced between spiro-OMeTAD and $\mathrm{TiO}_{2}$, and (c) spiroOMeTAD and $\mathrm{Al}_{2} \mathrm{O}_{3}$, following excitation at 500nm with an average pump energy density of 5.5 $\mu \mathrm{J} \cdot \mathrm{cm}^{-2}$. The dotted gray lines in all figures show steady state absorption spectra of corresponding samples.

Fig. 5. Scheme showing photoexcitation, charge carrier recombination and relaxation processes occurring within the perovskite solar cell. Inverted yellow color displays that the charge carrier recombination occurs predominantly within the perovskite absorber layer, and dark dotted circle represents trap-assisted recombination. 

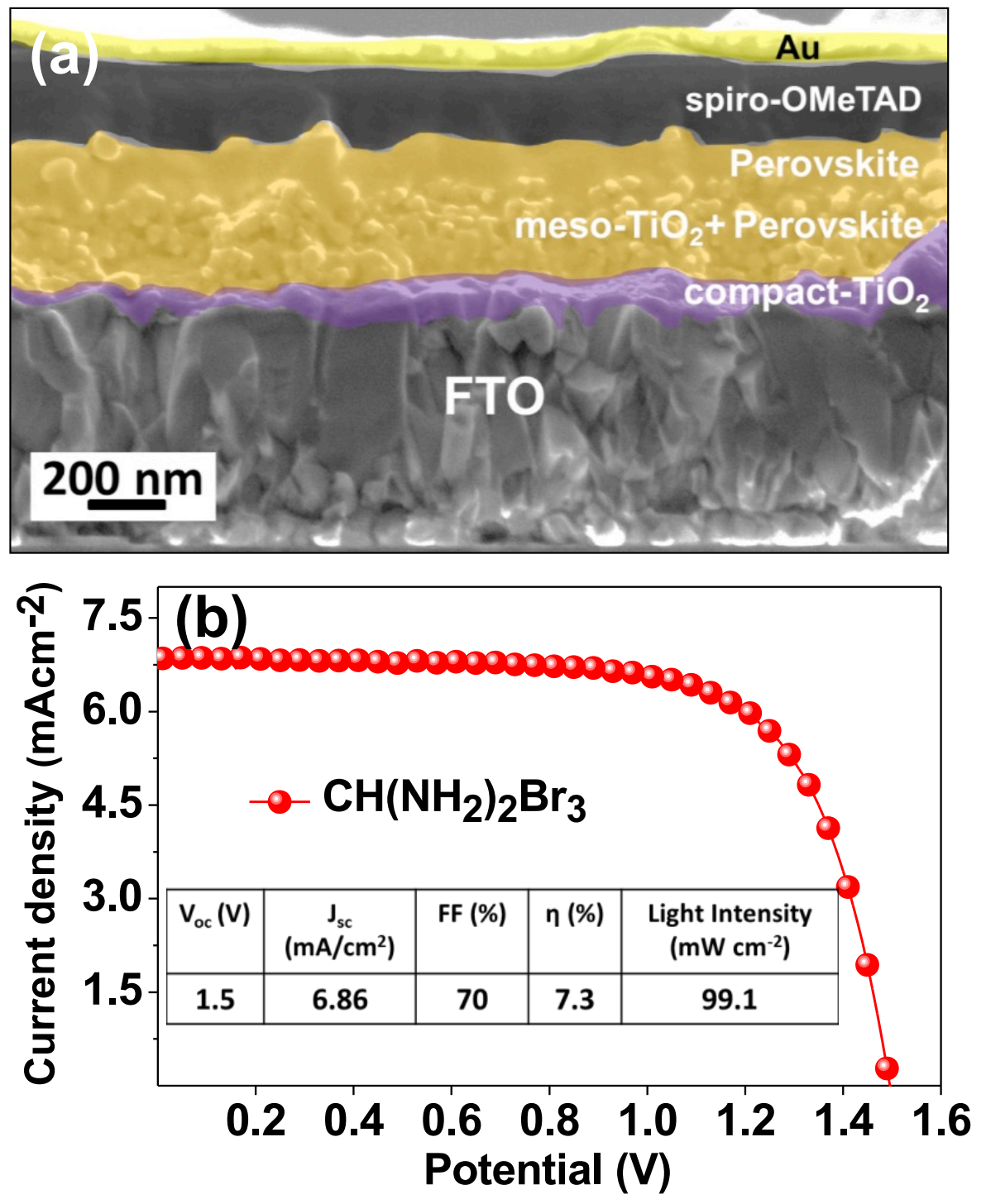
Fig. 1. Morphological analysis and photovoltaic study of $\mathrm{CH}\left(\mathrm{NH}_{2}\right)_{2} \mathrm{PbBr}_{3}$ solar cell. (a) Cross-sectional SEM image of a complete device and (b) Current-voltage curve recorded form $\mathrm{CH}\left(\mathrm{NH}_{2}\right)_{2} \mathrm{PbBr}_{3}$ device under standard illumination at $0.05 \mathrm{~V} / \mathrm{s}$ scan rate. (Ibrahim please add a graph with the IPCE data plus their integration over the AM1.5 solar emission to this Figure !. Also hysteresis should be discussed.) (Neha included hysteresis data (Fig. S1), but we don't have IPCE data, which will be provided during revision).
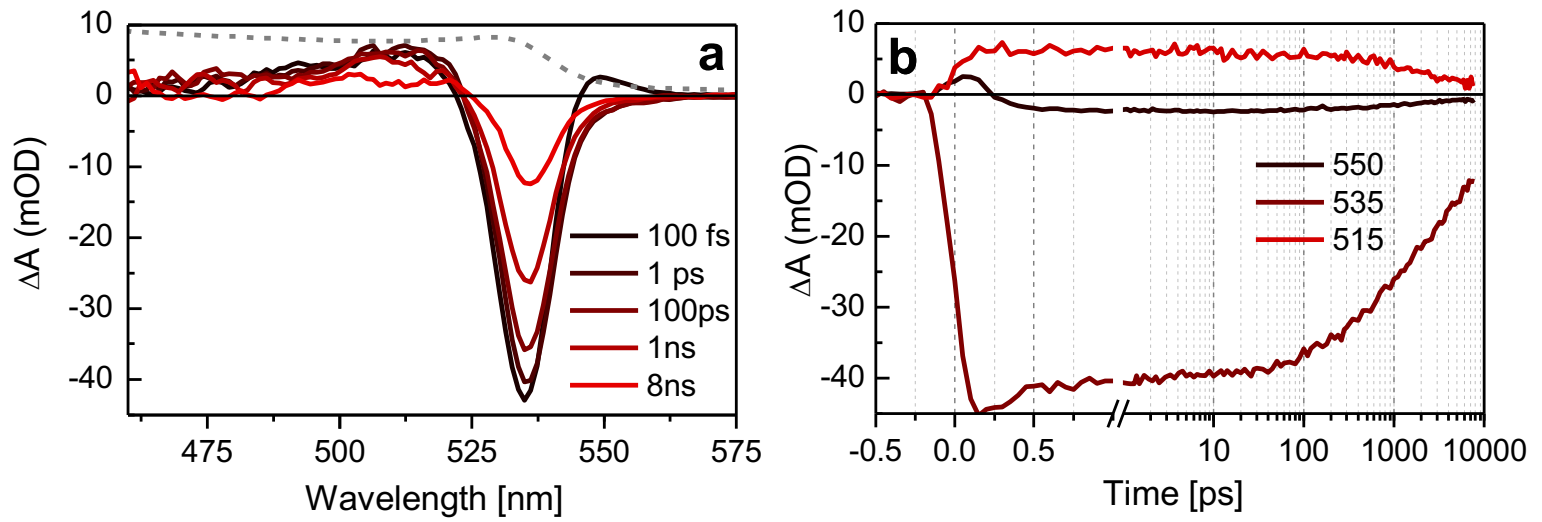

Fig. 2. (a) Transient absorption spectra and (b) decay kinetics of $\mathrm{CH}\left(\mathrm{NH}_{2}\right)_{2} \mathrm{PbBr}_{3}$ perovskite deposited onto insulating mesoporous $\mathrm{Al}_{2} \mathrm{O}_{3}$ layer, following excitation at 500nm with an average pulse energy density of $5.5 \mu \mathrm{J} \cdot \mathrm{cm}^{-2}$. The dotted gray line in (a) shows steady state absorption spectrum. 


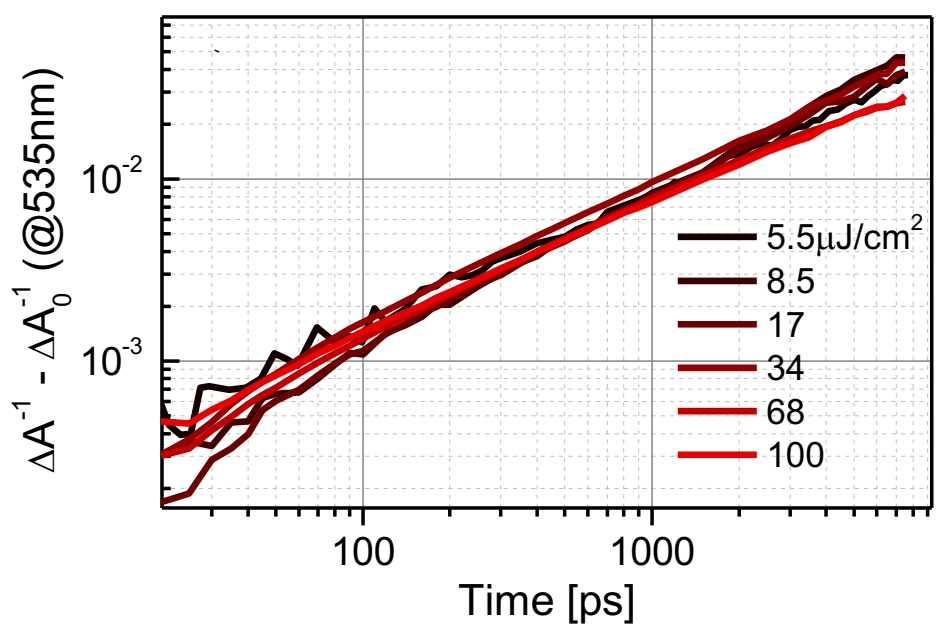

Fig. 3. Intensity dependent transient absorption decay kinetics of $\mathrm{CH}\left(\mathrm{NH}_{2}\right)_{2} \mathrm{PbBr}_{3}$ perovskite at $535 \mathrm{~nm}$ shown as the time dependence of $1 / \Delta A-1 / \Delta A_{0}$. 

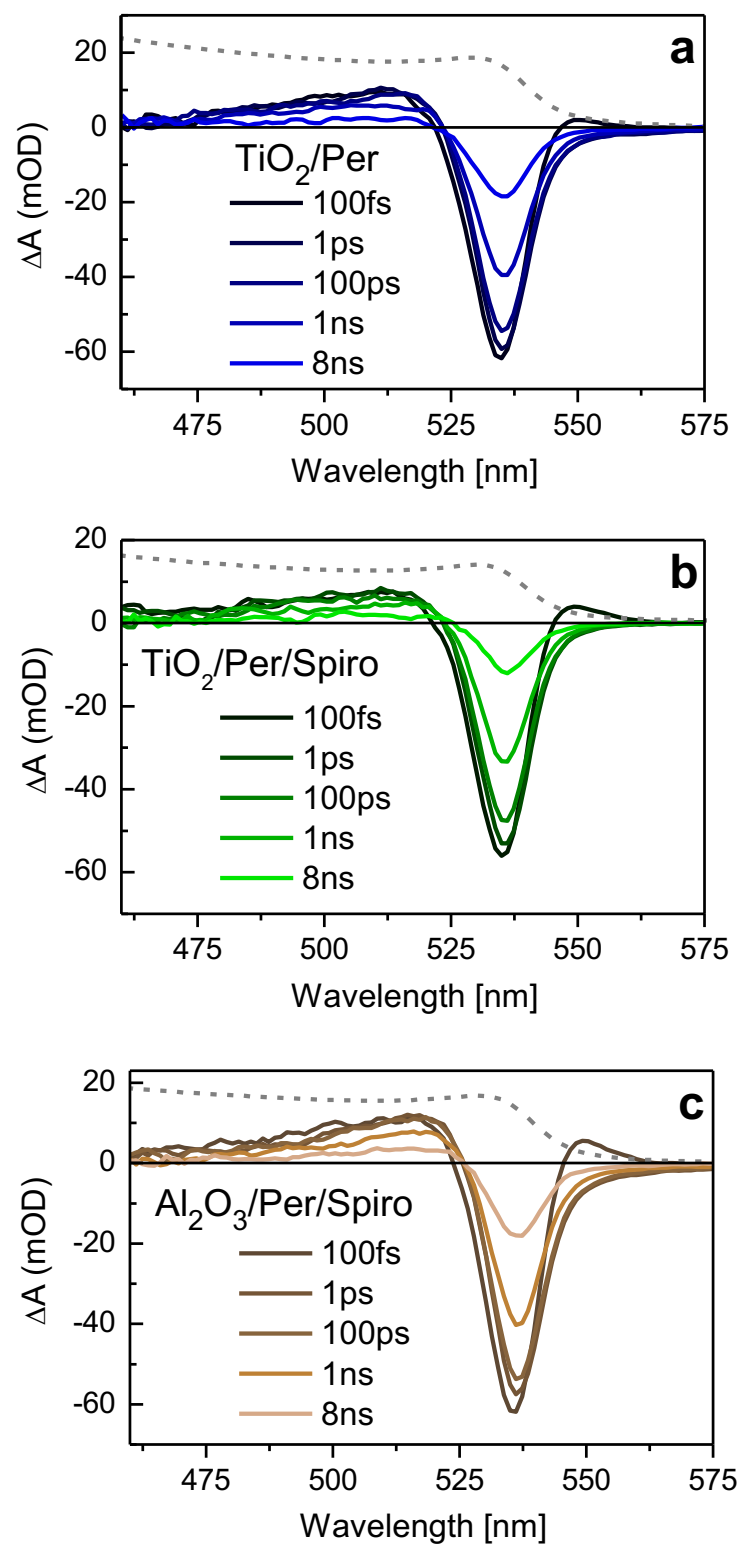

Fig. 4. Transient absorption spectra of $\mathrm{CH}\left(\mathrm{NH}_{2}\right)_{2} \mathrm{PbBr}_{3}$ perovskite films deposited onto (a) mesoporous $\mathrm{TiO}_{2}$ layer, (b) interfaced between spiro-OMeTAD and $\mathrm{TiO}_{2}$, and (c) spiroOMeTAD and $\mathrm{Al}_{2} \mathrm{O}_{3}$, following excitation at 500nm with an average pump energy density of 5.5 
$\mu \mathrm{J} \cdot \mathrm{cm}^{-2}$. The dotted gray lines in all figures shows steady state absorption spectra of corresponding samples.

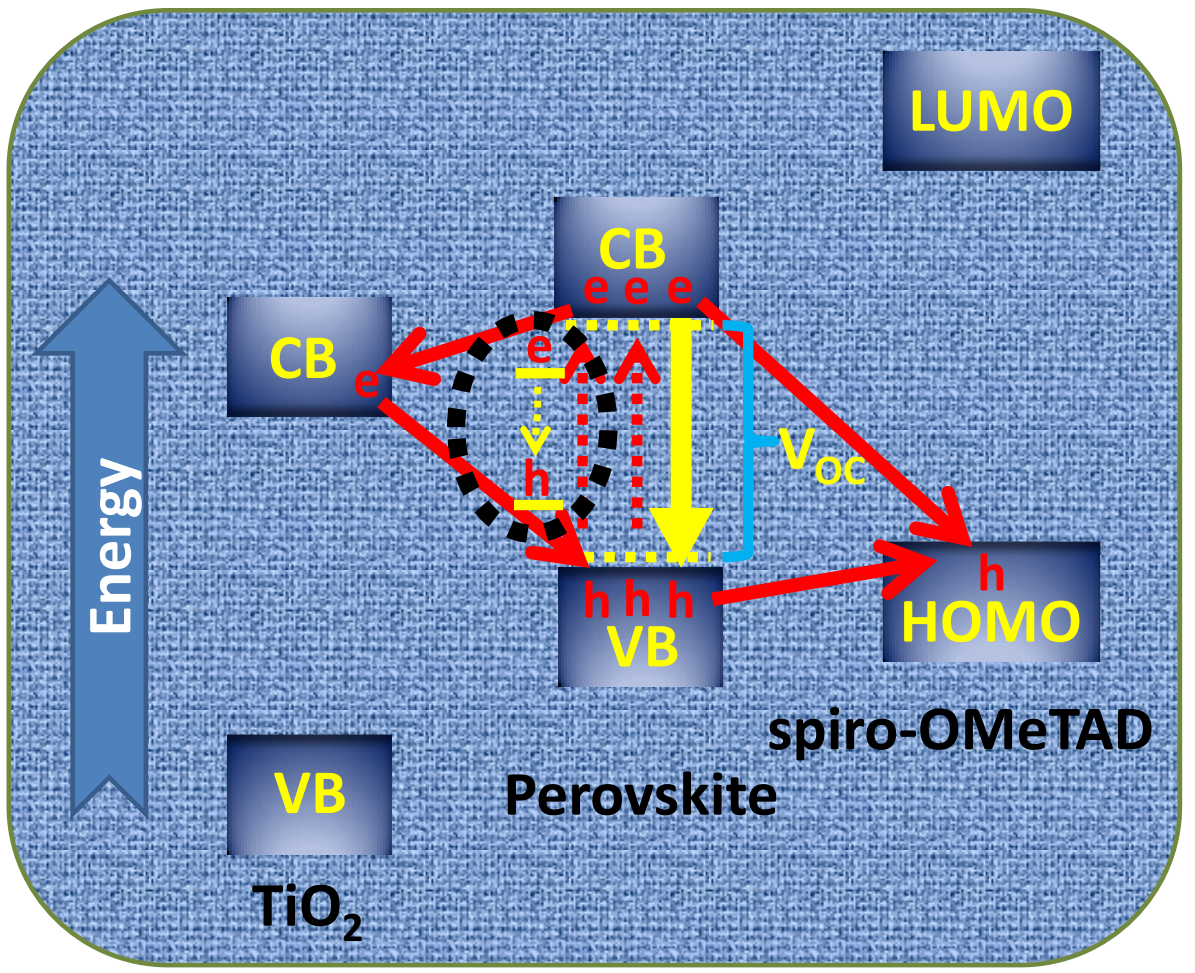

Fig. 5. Scheme showing photo-excitation, charge carrier injection, recombination and relaxation processes occurring within the perovskite solar cell. Inverted yellow color shows that the charge carrier recombination occurs predominantly within the perovskite absorber layer and dotted circle (dark color) represents trap-assisted recombination. 


\section{Graphical Abstract}

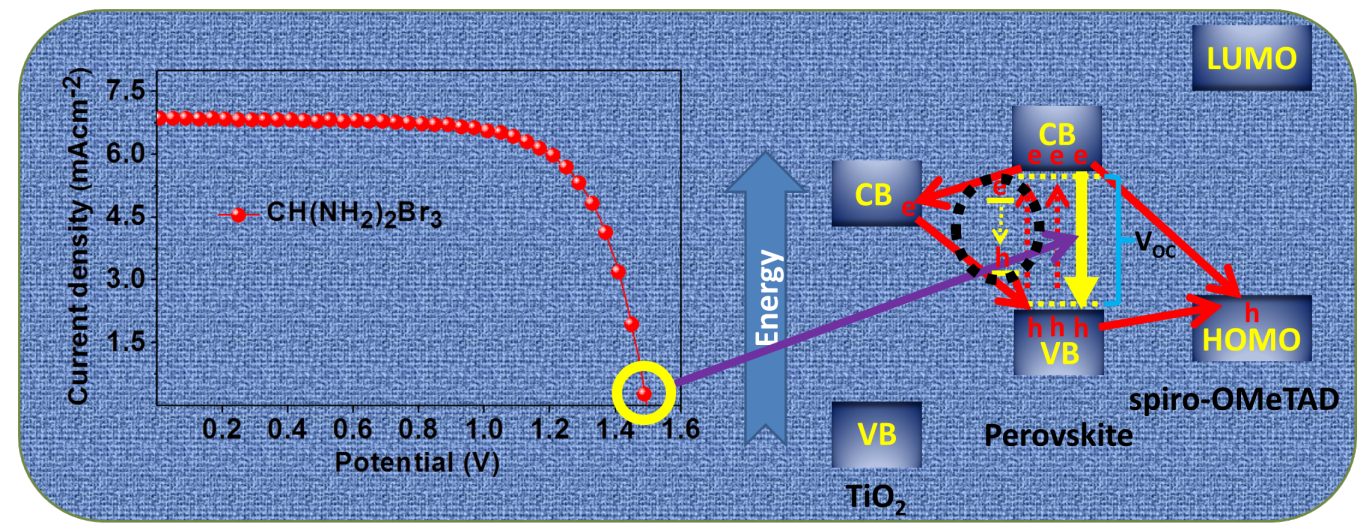




\section{Highlights}

- The critical understanding and the origin of $\mathrm{V}_{\mathrm{OC}}$ as high as $1.5 \mathrm{~V}$ displayed by $\mathrm{CH}\left(\mathrm{NH}_{2}\right)_{2} \mathrm{PbBr}_{3}$ solar cells is presented.

- In case of $\mathrm{CH}\left(\mathrm{NH}_{2}\right)_{2} \mathrm{PbBr}_{3}$, a negative band at $\sim 535 \mathrm{~nm}$ corresponding to the bleaching of the absorption band edge, and two positive absorption bands were revealed by transient absorption spectroscopy.

- We found that the presence of charge extraction layers exhibit insignificant effect on the excited state charge carrier dynamics in $\mathrm{CH}\left(\mathrm{NH}_{2}\right)_{2} \mathrm{PbBr}_{3}$ films.

- We contend that the quasi Fermi level splitting within the absorber layer predominantly determine the $\mathrm{V}_{\mathrm{OC}}$ in PSC. 


\section{Supporting information}

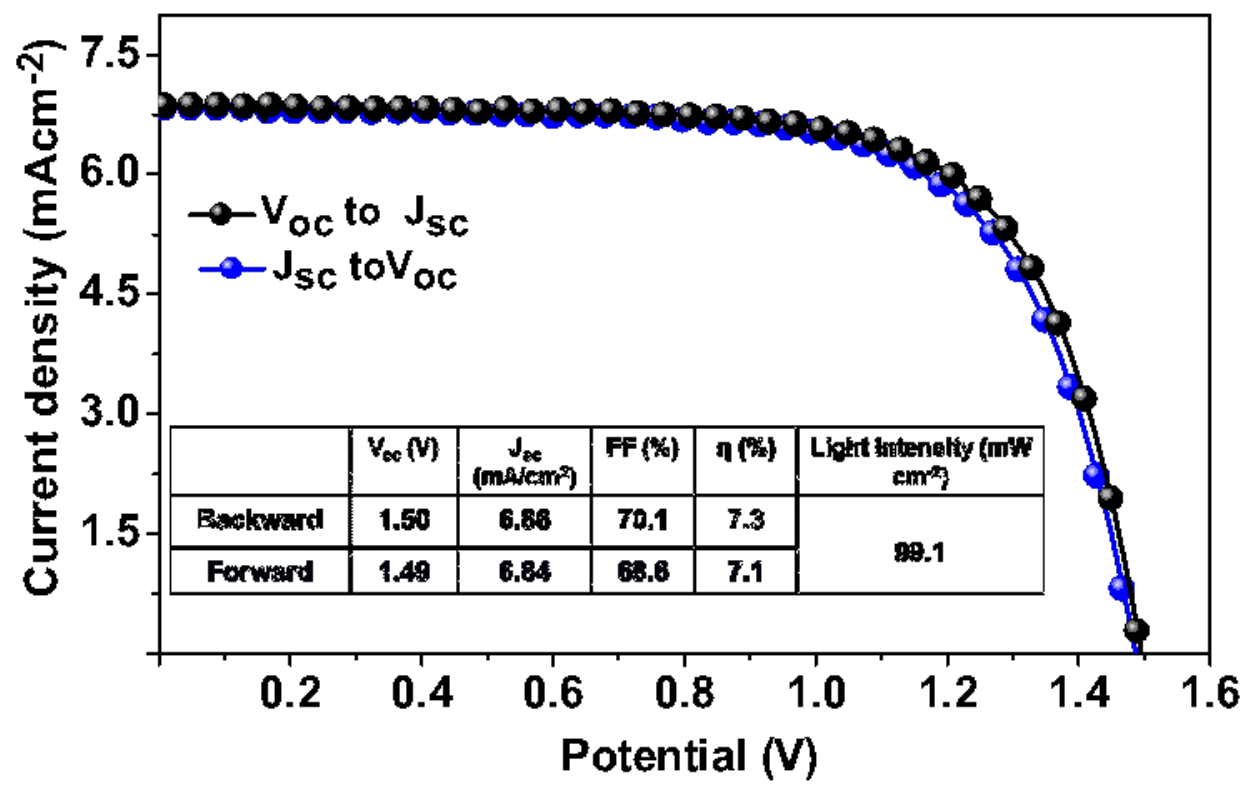

Fig. S1. Current-voltage hysteresis curve recorded form $\mathrm{CH}\left(\mathrm{NH}_{2}\right)_{2} \mathrm{PbBr}_{3}$ device under standard illumination at $0.05 \mathrm{~V} / \mathrm{s}$ scan rate. 


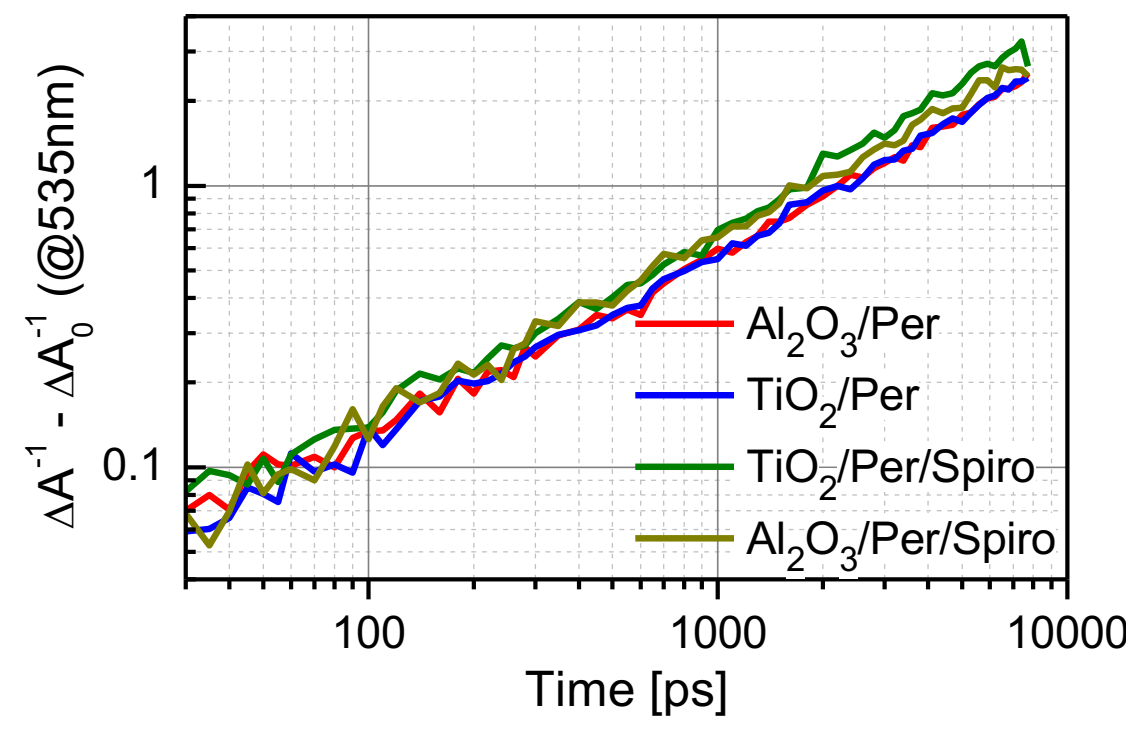

Fig. S2. Intensity dependent transient absorption decay kinetics of $\mathrm{CH}\left(\mathrm{NH}_{2}\right)_{2} \mathrm{PbBr}_{3}$ perovskites films interfaced with charge extracting and insulating layers at $535 \mathrm{~nm}$ shown as the time dependence of $1 / \Delta A-1 / \Delta A_{0}$. 